\title{
Acid Sphingomyelinase (ASM) is a Negative Regulator of Regulatory T Cell (Treg) Development
}

\author{
Yuetao Zhou ${ }^{a}$ Madhuri S. Salker ${ }^{\text {a }}$ Britta Walker ${ }^{\text {a }}$ Patrick Münzer ${ }^{\mathrm{a}}$ Oliver Borst $^{\mathrm{a}}$ \\ Meinrad Gawaz ${ }^{\mathrm{a}}$ Erich Gulbins ${ }^{\mathrm{b}, \mathrm{c}}$ Yogesh Singh ${ }^{\mathrm{a}}$ Florian Lang ${ }^{\mathrm{a}}$ \\ aDepartment of Cardiology, Vascular Medicine and Physiology I, Tuebingen University, Tuebingen, \\ bepartment of Molecular Biology, Medizinische Fakultät, Universitätsklinikum Essen, Essen, Germany; \\ 'Department of Surgery, University of Cincinnati, Cincinnati, OH, USA
}

\section{Key Words}

ASM • Treg • Inflammation

\begin{abstract}
Background/Aims: Regulatory $T$ cell (Treg) is required for the maintenance of tolerance to various tissue antigens and to protect the host from autoimmune disorders. However, Treg may, indirectly, support cancer progression and bacterial infections. Therefore, a balance of Treg function is pivotal for adequate immune responses. Acid sphingomyelinase (ASM) is a rate limiting enzyme involved in the production of ceramide by breaking down sphingomyelin. Previous studies in T-cells have suggested that ASM is involved in CD28 signalling, T lymphocyte granule secretion, degranulation, and vesicle shedding similar to the formation of phosphatidylserine-exposing microparticles from glial cells. However, whether ASM affects the development of Treg has not yet been described. Methods: Splenocytes, isolated Naive $\mathrm{T}$ lymphocytes and cultured T cells were characterized for various immune $T$ cell markers by flow cytometery. Cell proliferation was measured by Carboxyfluorescein succinimidyl ester (CFSE) dye, cell cycle analysis by Propidium Iodide (PI), mRNA transcripts by q-RT PCR and protein expression by Western Blotting respectively. Results: ASM deficient mice have higher number of Treg compared with littermate control mice. In vitro induction of ASM deficient T cells in the presence of TGF- $\beta$ and IL-2 lead to a significantly higher number of Foxp3+ induced Treg (iTreg) compared with control T-cells. Further, ASM deficient iTreg has less AKT (serine 473) phosphorylation and Rictor levels compared with control iTreg. Ceramide C6 led to significant reduction of iTreg in both ASM deficient and WT mice. The reduction in iTreg leads to induction of IL-1 $\beta$, IL- 6 and IL-17 but not IFN $-\gamma$ mRNA levels. Conclusion: ASM is a negative regulator of natural and iTreg.

\section{Introduction}

Regulatory T cells $\left(\mathrm{CD} 4^{+} \mathrm{CD} 25^{+} \mathrm{Foxp}^{+}{ }^{+}\right.$Treg) are pivotal for maintaining tolerance to self and non-self-antigens and protect the hosts from numerous autoimmune pathologies [1-3].

Yogesh Singh

Florian Lang

KARGER
Department of Physiology, Cardiology and Vascular Medicine Tuebingen University, Tuebingen, Gmelinstraße5, 72076 Tuebingen (Germany)

Tel.+49(0)7071 29-72194, Fax +49 (0)7071 29-3073

E-Mail ysinghbt@gmail.com / florian.lang@uni-tuebingen.de 
However, in contrast, Treg can also favour cancer progression and bacterial infections [4-9]. Recently, Treg has been described as being neuroprotective, by modulating oxidative stress and inflammation in microglial cells, thereby ameliorating neurodegeneration in Parkinson's disease $[10,11]$. The development, maintenance, and effector function of Treg is dependent on the cardinal transcription factor Foxp3 [12-17].

Sphingolipids are a class of lipids with a polar head group and two nonpolar tails. The core of a sphingolipid is an amino alcohol called sphingosine $[18,19]$. Complex sphingolipids located in the plasma membrane of cells (in particular nerve cells) have a structural function and are believed to protect the cell surface from harmful environmental factors and the regulation of inflammation, cell death, and cell proliferation involves sphingolipids [18]. They also serve as adhesion sites for extracellular proteins and play important roles in signal transmission and cell recognition. Metabolites derived from sphingolipids have been associated with development of several pathologies including diabetes, cancer, microbial infections, neurological syndromes, and cardiovascular disease [18]. Sphingolipid metabolism involves several enzymes creating a balance between synthesis and degradation of sphingolipids [19]. Sphingolipids catabolism by sphingomyelinase leads to generation of ceramides $[19,20]$.

The activity of sphingomyelinases is pH dependent [21]. Two distinct sphingomyelinases have been defined, an acid sphingomyelinase (ASM) located in the lysosomes and neutral sphingomyelinase (NSM) located on the outer leaflet of the plasma membrane [22]. Furthermore, depending on glycosylation pattern of ASM, the enzyme is located either in lysosomes or the enzyme is secreted [21]. ASM is needed to hydrolyse sphingomyelin into ceramide and phosphocholine [22]. Deficiency of this enzyme leads to Niemann-Pick disease (NPD) in humans [22, 23]. Deregulated ASM function is involved in many pathologies including; inflammation and infection, cystic fibrosis, Wilson disease, type 2 diabetes, cardiovascular disease, cerebral ischemia, autoimmune multiple sclerosis, major depression, Parkinson disease, and Alzheimer's disease [19, 21, 23-28]. In platelets, ASM regulates cell membrane scrambling, secretion and thrombus formation [29]. In primary CD8 ${ }^{+} \mathrm{T}$ cells, ASM is a prime regulator of cytotoxic granule secretion [30] and ASM is involved in regulation of CD95 dependent cell death [31]. However, whether ASM regulates the development of $\mathrm{CD} 4^{+} \mathrm{CD} 25^{+} \mathrm{Foxp}^{+}$regulatory $\mathrm{T}$ cells (Tregs) remains elusive.

The present study thus explored whether ASM affects Treg development. As a result, ASM deficient $\left(\mathrm{ASM}^{-/}\right)$mice had significantly higher total number of $\mathrm{CD}^{+} \mathrm{CD}_{2} 5^{+} \mathrm{Foxp} 3^{+}$ Treg cells compared with WT littermates $\left(\mathrm{ASM}^{+/+}\right)$in vivo. Differentiation of $\mathrm{CD}^{+} \mathrm{T}$ cells into Foxp $3^{+}$induced Treg (iTregs) in the presence of TGF- $\beta$ and IL-2 lead to statistically higher percentage of iTreg from $\mathrm{ASM}^{-/}$compared with $\mathrm{ASM}^{+/+}$mice. iTreg development was dependent on AKT/Rictor. ASM $\%$ iTregs were less proliferative and less suicidal compared with $\mathrm{ASM}^{+/+}$iTreg. Further, the ASM product ceramide compromised iTreg development with higher mRNA levels of inflammatory cytokines (IL-1 $\beta$, IL-6 and IL-17) in iTreg. Thus, our data suggest that ASM plays an important role in the regulation of Treg development by regulating ceramide production.

\section{Materials and Methods}

Mice

Male and Female (8-12 weeks old) $\mathrm{ASM}^{+/+}$and $\mathrm{ASM}^{-/-}$mice were used as described previously [29]. All experiments used littermate controls of matched sex and were performed according to the EU Animals Scientific Procedures Act and the German law for the welfare of animals. The procedures were approved by the authorities of the state of Baden-Württemberg.

$C D 4^{+} T$ cell purification

$\mathrm{T}$ cells are purified as describe earlier [32]. In brief, from 8-12 weeks old mice, spleens were collected and macerated utilised a syringe plunger. Cells were then used for naïve $\mathrm{CD}^{+} \mathrm{CD} 25^{-} \mathrm{T}$ cells purification 


\section{Cellular Physiology Cell Physiol Biochem 2016;39:985-995 \\ \begin{tabular}{l|l|l}
\hline and Biochemistry $10.1159 / 000447806$ & $\begin{array}{l}\text { C) } 2016 \text { The Author(s). Published by S. Karger AG, Basel } \\
\text { www.karger.com/cpb }\end{array}$ \\
\hline
\end{tabular} \\ Zhou et al.: ASM Plays a Key Role in Treg Development}

using magnetic beads selection. Negative selection of $\mathrm{CD} 4^{+} \mathrm{T}$ cells method was applied to isolate $\mathrm{CD} 4^{+} \mathrm{T}$ cells. Shortly, the cell suspension was centrifuged at $600 \mathrm{xg}$ at $4^{\circ} \mathrm{C}$ for 5 minutes and the cell pellet was treated with RBC lysis buffer for 1 minute and then washed for three times with 10\% RPMI1640 medium (Invitrogen, Germany). After washing the cells, $50 \mu \mathrm{l}$ /mouse antibody mix containing anti-CD8, anti-MHC II, anti-CD11b, anti-CD16/32, anti-CD45R, and Ter-119 (Dynabeads® ${ }^{\circledR}$ Untouched $^{\text {TM }}$ Mouse CD4 cells kit, Invitrogen, Germany) was added onto cells and cells were incubated on a roller in $4^{\circ} \mathrm{C}$ room for 30 minutes. Cells were then washed, counted and added 1:1 (cells to beads ratio) Dynabeads in $1.0 \mathrm{ml}$ media per mouse and kept at $4^{\circ} \mathrm{C}$ room for 30 minutes on a roller for bounding the $\mathrm{CD}^{+} \mathrm{T}$ cells, $\mathrm{B}$ cells, NK cells, monocytes/macrophages, dendritic cells, erythrocytes and granulocytes. All these Dyanbeads-bound cells were captured utilising the Magnet stand (DynaMag ${ }^{\mathrm{TM}} 5$ Magnet), and the supernatant containing CD4 ${ }^{+} \mathrm{T}$ cells was then collected.

\section{iTreg differentiation}

To differentiate naïve $\mathrm{T}$ cells into iTreg, plates were pre-treated with a ratio of 1:2:anti-CD3:anti-CD28 $\left(1.0 \mu \mathrm{g} / \mathrm{ml}\right.$ anti-CD3: $2.0 \mu \mathrm{g} / \mathrm{ml}$ anti-CD28) [11]. CD4 ${ }^{+}{ }^{-} D 25^{-} \mathrm{T}$ cells were then activated after incubated 3-4 days in RPMI1640 medium (Invitrogen) supplemented with FBS, Penicillin/Steptomycin, L-glutamine, $\beta$-Mercaptoethanol [32] on the plate bound with anti-CD3/anti-CD28 antibodies (eBiosciences, UK), and $5.0 \mathrm{ng} / \mathrm{ml}$ recombinant-TGF- $\beta, 10.0 \mathrm{ng} / \mathrm{ml}$ recombinant-IL-2 (eBiosciences, Germany) were added during

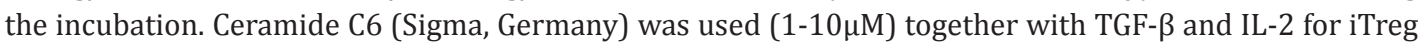
differentiation. Cells were harvested at day 3-4 and used for flow cytometry, q-RT-PCR and immune-blotting experiments.

\section{Flow cytometry}

Splenocytes or activated Th0 and iTreg from $\mathrm{ASM}^{+/+}$and $\mathrm{ASM}^{-/-}$mice were collected and incubated with florescence bound anti-CD4, anti-CD8a, anti-CD25, anti-CD62L, anti-CD44 (eBioscience, Germany) for surface staining for characterisation, or other antibodies depending on the experiment and washed with PBS. For intracellular staining cells were then fixed with Foxp3 fixation/permeabilization buffer (eBioscience, Germany) for 45 minutes and then washed with 1x permeabilization buffer. After washing, cells were exposed to intracellular monoclonal antibodies for Foxp3 or other antibodies depending on the experiment and incubated for additional 45 minutes. Cells were then washed again with permeabilization buffer and PBS was added to acquire the cells on a flow cytometer (FACS-calibur from Becton Dickinson; Heidelberg, Germany).

\section{Cell cycle analysis}

After Th0 and iTreg culture, cells were collected and washed with PBS at $600 \mathrm{xg}$ for 5 minutes at RT. $1 \mathrm{ml}$ of $-20^{\circ} \mathrm{C}$ cold ethanol:PBS mix (3:1) was added during swirl mixing of the cells pellet. Cells were then kept at $-20^{\circ} \mathrm{C}$ overnight to maximum 4 days depending on the experiment. After incubation at $-20^{\circ} \mathrm{C}$, cells were washed with PBS again and incubated for 30 minutes at RT in the presence of $50 \mu \mathrm{g} / \mathrm{ml}$ PI (Sigma, Germany) and $100 \mu \mathrm{g} / \mathrm{ml}$ RNase A (Qiagen, Germany). To the end, cells were washed and acquired by flow cytometry for cell cycle and cell death analysis.

\section{CFSE staining and cell proliferation}

After $\mathrm{CD} 4^{+} \mathrm{T}$ cells were purified, cells $\left(5 \times 10^{6}\right)$ were washed $1 \mathrm{x}$ with PBS (Sigma, Germany) and stained with $2 \mu \mathrm{M}$ Carboxyfluorescein succinimidyl ester (CFSE) (eBioscience, Germany) for 15 minutes at RT in the dark and washed $2 \mathrm{x}$ with RPMI-1640 medium as described earlier [32]. Stained cells were cultured for 3 days and after 3 days of culture, cells were stained with Foxp3 antibody and detected by flow cytometry.

\section{Immunoblotting}

Activated naïve $\mathrm{T}$ cells $\left(1 \times 10^{6}\right.$ cells $)$ from $\mathrm{ASM}^{+/+}$and $\mathrm{ASM}^{-/}$were differentiated into iTreg by introducing TGF- $\beta$ and IL-2 and after 3 days of culture, cells were then collected and washed $1 \mathrm{x}$ with PBS. After washing, 1:1 ratio $\mathrm{H}_{2} \mathrm{O}$ and $2 \mathrm{X}$ Lammelli's Buffer were added for cell lysis. Proteins was then denatured at $95^{\circ} \mathrm{C}$ for 5 minutes and stored at $-20^{\circ} \mathrm{C}$. For each condition of experiments, sample proteins were loaded on $8 \%$ or $10 \%$ SDS-PAGE gel depending on proteins size and run for $80-120 \mathrm{mV}$ for $90-100$ minutes. Proteins were then electrotransferred onto PVDF membrane (GE healthcare, USA). Membranes 


\section{Cellular Physiology Cell Physiol Biochem 2016;39:985-995

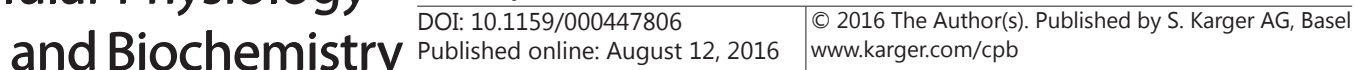 \\ Zhou et al.: ASM Plays a Key Role in Treg Development}

were probed with the indicated primary antibodies (pAktS473, mTOR, Rictor, pS6 ribosomal protein (S235) S236), and GAPDH; Cell Signalling, USA) followed by HRP-conjugated secondary antibodies (Cell Signalling, USA) [33]. Membranes were washed and visualized with enhanced chemiluminescence detection system (ECL; PeqLab, Germany).

\section{q-RT-PCR}

Total mRNA was isolated from Th0 cells and iTregs from $\mathrm{ASM}^{+/+}$and $\mathrm{ASM}^{-/-}$using the mRNAeasy isolation kit (QIAGEN, Germany) as described by the manufacturer. $1.0 \mu \mathrm{g}$ mRNA was converted into cDNA using the Superscript III cDNA synthesis kit (Invitrogen, Germany). Briefly, in $10.0 \mu$ l reactions, 10.0 ng cDNA, 2X SYBR green Master-mix (KAPA SYBR green, Peqlab, Germany) and 250 nM primers were used for q-RT-PCR reactions. q-RT-PCR and data analysis were performed using ${ }^{-\Delta \Delta} \mathrm{CT}$ method. Primer sequences used in this study; Foxp3 F primer: 5'- GGTACACCCAGGAAAGACAG-3' and R primer: 5'- ATCCAGGAGATGATCTGCTTG-3', IL-1 $\beta$ F primer: 5'- TACCTGTGGCCTTGGGCCTCAA-3' and R primer: 5'GCTTGGGATCCACACTCTCCAGCT-3', IL-6 F primer: 5'- TGGAGTCACAGAAGGAGTGGCTAAG-3' and R primer: 5' - TCTGACCACAGTGAGGAATGTCCAC-3', IL-17 F primer: 5'- CTCCAGAAGGCCCTCAGACTAC-3' and R primer: 5'- AGCTTTCCCTCCGCATTGACACAG-3', IFN- $\gamma$ F primer: 5'- GGCTGTTACTGCCACGGCACA-3' and R primer: 5'- CACCATCCTTTTGCCAGTTCCTCCA-3' and GAPDH: F primer: 5'-CGTCCCGTAGACAAAATGGT-3' and R primer: 5'-TTGATGGCAACAATCTCCAC-3' primers using universal cycling conditions $\left(95^{\circ} \mathrm{C}\right)$ for 3 minutes, $95^{\circ} \mathrm{C}$ for 15 seconds and $60^{\circ} \mathrm{C}$ for 1 minute for 40 cycles followed by melting curve analysis). All primers were purchased from Sigma.

\section{Statistics}

Figures were made in Excel Microsoft office software. Arithmetic mean values are presented \pm standard error of mean (SEM) and $n$ represents the number of independent biological experiments. GraphPad Prism and Excel were used for statistical analyses. Student's unpaired t-test was used for significance. P values of equal or less than 0.05 were considered significant, $\mathrm{p} \leq 0.05^{*}, \mathrm{p} \leq 0.01^{* *}$ and $\mathrm{p} \leq 0.001^{* * *}$.

\section{Results}

ASM deficiency leads to increase in total $\mathrm{CD}^{+} \mathrm{CD}^{+} 5^{+} \mathrm{Foxp} 3^{+}$Treg

The present study explored whether ASM influences CD4 ${ }^{+} \mathrm{T}$ cells development. In a first series of experiments, we stained splenocytes from $\mathrm{ASM}^{-/-}$and $\mathrm{ASM}^{+/+}$mice for various $\mathrm{T}$ cell markers such as CD4, CD8, CD25, Foxp3, CD44 and CD62L. CD4 ${ }^{+}$or $\mathrm{CD}^{+} \mathrm{T}$ cells numbers tended to be higher in $\mathrm{ASM}^{-/}$mice than in $\mathrm{ASM}^{+/+}$mice, a difference, however, not reaching statistical significance (Fig. 1A). CD4 ${ }^{+}$T cells were stained for CD25 and Foxp3 to identify the Treg population in both mice strains. As a result, $\mathrm{ASM}^{-/-}$mice had significantly higher (total) number of Treg compared with $\mathrm{ASM}^{+/+}$mice (Fig. 1B). We found no significant difference in between $\mathrm{ASM}^{-/}$and $\mathrm{ASM}^{+/+}$mice for naïve $\mathrm{CD}^{+} \mathrm{T}$ cells $\left(\mathrm{CD}^{+} \mathrm{CD}^{+} 4^{-} \mathrm{CD}^{-} \mathrm{L}^{+}\right.$). Memory $\left(\mathrm{CD} 4{ }^{+} \mathrm{CD} 44^{+} \mathrm{CD} 62 \mathrm{~L}^{-}\right) \mathrm{T}$ cells tended to be higher based on total numbers of cells in $\mathrm{ASM}^{-/-}$ compared with $\mathrm{ASM}^{+/+}$mice, a difference, however, not reaching statistical significance (Fig. 1C).

\section{ASM deficiency increases the $C D 4^{+}$Foxp $^{+}$iTreg}

As revealed in Figure 1, ASM deficient mice possess higher numbers of Treg, we next explored whether ASM deficiency also lead to the increased development of CD4 ${ }^{+}$ Foxp $3^{+}$iTreg in these mice. We isolated naïve $\mathrm{CD}^{+}{ }^{+} \mathrm{T}$ cells from both $\mathrm{ASM}^{-/-}$and $\mathrm{ASM}^{+/+}$ mice spleen and differentiated in vitro into iTreg in the presence of TGF- $\beta$ and IL-2. After 3-4 days of differentiation we found no significant change in the control (Th0) cells from $\mathrm{ASM}^{-/-}$compared with $\mathrm{ASM}^{+/+}$mice (Fig. 2A, B), however, $\mathrm{ASM}^{-/-}$mice have significantly higher percentage of iTreg compared with $\mathrm{ASM}^{+/+}$mice (Fig. 2A, C).

As previously described, activated levels of AKT/Rictor was shown to attenuate the development of Tregs [11, 34, 35]. As illustrated in Figure 2D, we showed that iTreg from $\mathrm{ASM}^{-/}$mice have a reduction in Rictor, mTOR and AKT (serine 473) phosphorylation protein 
Fig. 1. Peripheral development of Tregs in ASM deficient mice. (A) $\mathrm{ASM}^{+/+}$and $\mathrm{ASM}^{-/-}$splenocytes were stained with anti-CD4 and anti-CD8 $\mathrm{mAbs}$ and characterised for CD4 and CD8 expression. No significant difference was observed between $\mathrm{ASM}^{+/+}$and $\mathrm{ASM}^{-/-} \mathrm{CD}^{+}$ and $\mathrm{CD}^{+} \mathrm{T}$ splenocytes. Left hand side shows a representative FACS plots for CD4 and CD8 staining and right hand side shows the mean \pm SEM ( $\mathrm{n}=3-5$ independent experiments). (B) Splenocytes were stained with CD4, CD8, CD25 and Foxp3 antibodies and splenocytes were gated on $\mathrm{CD}^{+}{ }^{+} \mathrm{T}$ cells. $\mathrm{CD}^{+} \mathrm{T}$ cells were characterised for Tregs markers CD25 and Foxp3. As a result, Total number of $\mathrm{CD}^{2} 5^{+}$Foxp3 ${ }^{+}$Treg is significantly more abundant in $\mathrm{ASM}^{\%}$ mice than in
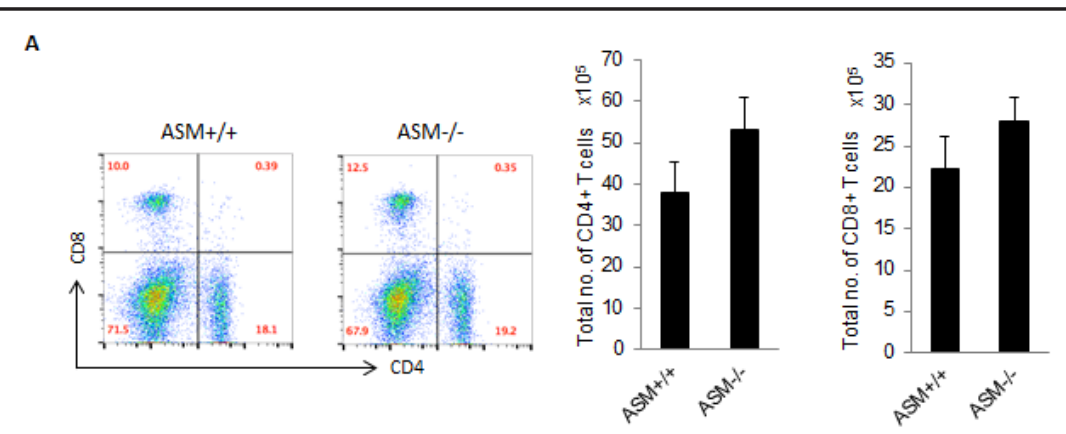

B
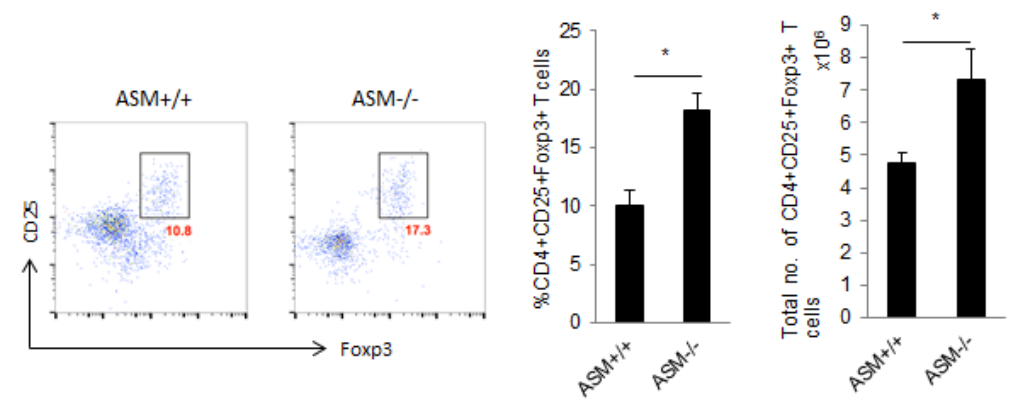

C
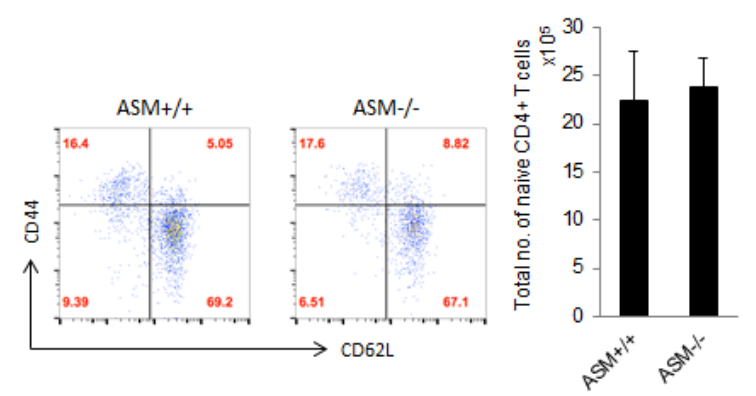

$\mathrm{ASM}^{+/+}$mice. Left hand side shows a representative FACS plots for CD25 and Foxp3 staining gated on CD4 ${ }^{+}$ $\mathrm{T}$ cells and right hand side shows mean \pm SEM $(\mathrm{n}=3-5$ independent experiments). * indicates statistical significance difference ( $\mathrm{p}<0.05)$. (C) $\mathrm{CD}^{+} \mathrm{T}$ cells were characterized for naïve and memory $\mathrm{T}$ cells markers and based on CD44 and CD62L expression, no significant difference was observed in between $\mathrm{ASM}^{+/+}$and $\mathrm{ASM}^{-/}$mice. Left hand side shows a representative FACS plots for CD44 and CD62L staining gated on CD4 ${ }^{+}$ $\mathrm{T}$ cells and right hand side shows mean \pm SEM ( $\mathrm{n}=3-5$ independent experiments) for CD44 and CD62L expression.

levels when compared to iTreg from $\mathrm{ASM}^{+/+}$mice. Further to this, we show that Phospho-S6 is also lower, reflecting lower activated mTOR activity (Fig. 2D). Therefore, these results suggest ASM may contribute to the increased development of iTreg through AKT/Rictor pathway.

\section{ASM is involved the regulation of iTreg proliferation}

In order to test, whether ASM regulates the proliferative capability in iTreg, we stained the naïve $\mathrm{CD} 4^{+} \mathrm{T}$ cells with carboxyfluorescein succinimidyl ester (CFSE; a cell proliferation dye) and differentiated T cells into iTreg in the presence of TGF- $\beta$ and IL-2. After 3 days of culture, differentiated cells were stained for Foxp3 and proliferation activity of iTreg $\left(\right.$ Foxp $^{+}$) was measured. As illustrated in Fig. 3A iTreg from $\mathrm{ASM}^{-/-}$mice have a significantly lower proliferative capacity when compared to $\mathrm{ASM}^{+/+}$mice. Cell cycle analysis suggested that $\mathrm{ASM}^{-} \%$ iTreg has significantly lower percentage of cell in the G0/G1 phase compared 
Fig. 2. ASM deficient mice T cells are superior in induction of iTreg and ASM deficiency reduced the AKT/mTOR signalling pathways via TCR activation in iTreg. Purified $\mathrm{CD}^{+} \mathrm{T}$ cells were cultured for 3 days with TGF- $\beta$ (5.0 $\mathrm{ng} / \mathrm{ml}$ ) and IL-2 (10.0 ng/ml) (iTreg) or remained untreated (Th0). After 3 days of culture cells were stained with a Foxp3 antibody and acquired by flow cytometry. Flow data suggested $\mathrm{ASM}^{-/}$mice have significantly higher iTreg compared to $\mathrm{ASM}^{+/+}$mice. (A) Representative FACS plots for Foxp3 staining in Th0 (upper) and iTreg (lower). (B-C) shows means \pm SEM ( $\mathrm{n}=$ 3-5 independent experiments) for Th0 cells and iTreg. ** indicates statistical significance difference $(p<0.01)$. (D) $\mathrm{ASM}^{-/}$iTreg has lower phosphorylation of AKT and S6 kinase and expression of mTOR and Rictor proteins compared with $\mathrm{ASM}^{+/+}$iTreg. Data are shown from 3-5 biological replicate mice.

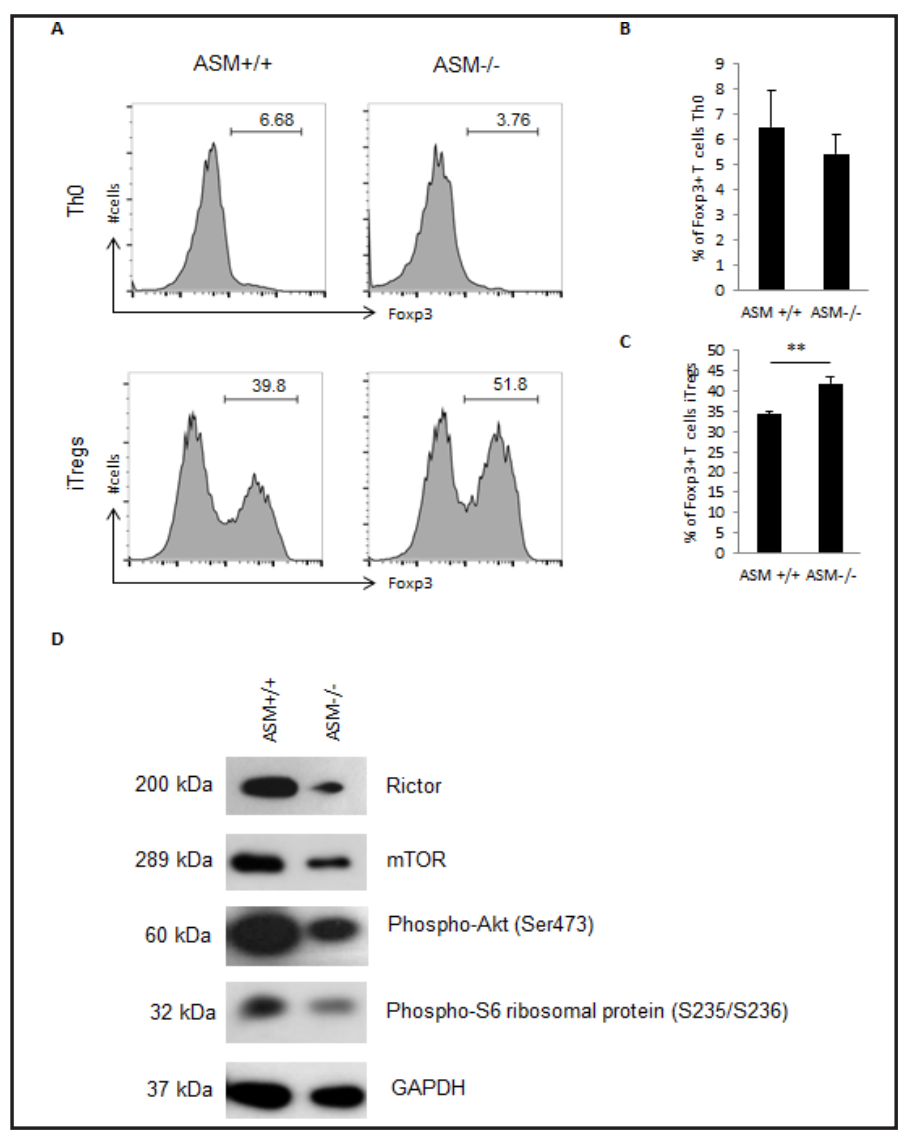

Fig. 3. ASM deficient mice have reduced proliferation of iTreg and progression of cell cycle. (A) Purified CD4+ T cells were stained with the cell proliferation dye CFSE $(2 \mu \mathrm{M})$ and cultured for 3 days with TGF- $\beta$ $(5.0 \mathrm{ng} / \mathrm{ml})$ and IL-2 (10.0 ng/ $\mathrm{ml}$ ) (iTreg). After 3 days of culture cells were stained with a Foxp3 antibody and acquired by flow cytometry. Flow data suggested $\mathrm{ASM}^{-/}$mice have significantly lower proliferation rates in iTreg compared with $\mathrm{ASM}^{+/+}$mice. Left hand side shows the representative FACS plots for Foxp3 and CFSE

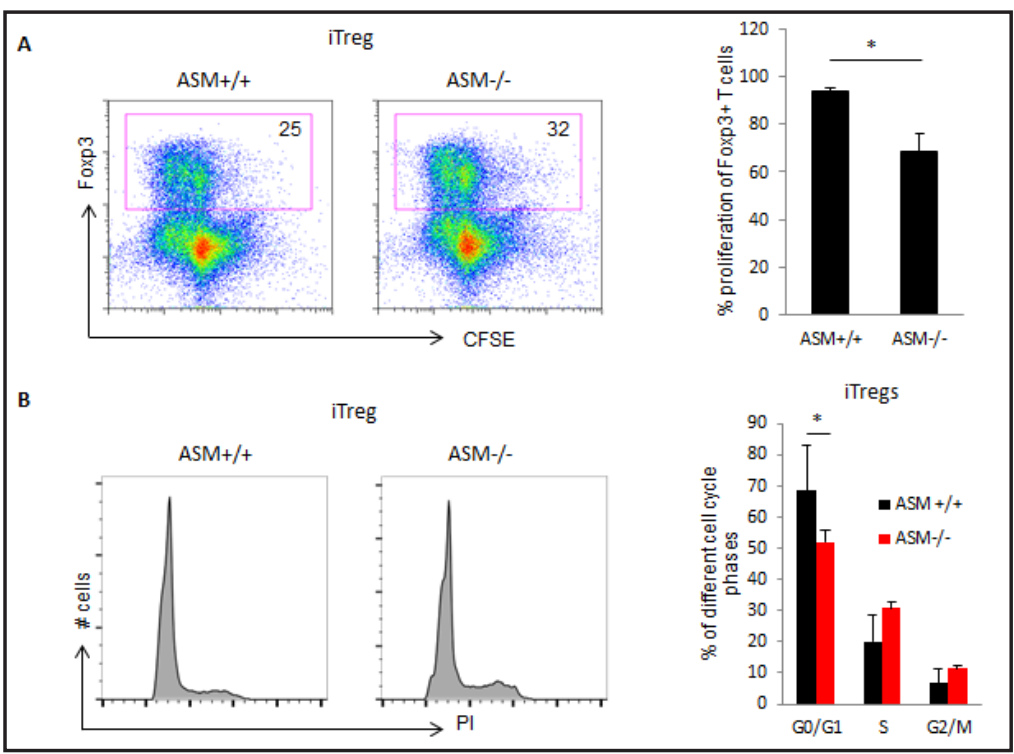
staining and right hand side shows mean \pm SEM ( $\mathrm{n}=3-5$ independent experiments) for iTreg. * indicates statistical significance difference $(p<0.05)$. (B) Cell Cycle of iTreg was characterised by Propidium Iodide (PI) staining. PI staining suggested iTreg from $\mathrm{ASM}^{-/-}$mice have significantly fewer G0-G1 cell cycle stages and significantly more S phase stages compared with $\mathrm{ASM}^{+/+}$iTreg at percentage level. Data are shown as mean \pm SEM $(n=3-5$ independent experiments). * indicates statistical significance difference $(p<0.05)$.

with $\mathrm{ASM}^{+/+}$iTreg (Fig. 3B). No difference was seen in S or G2/M phases and in cell death (data not shown). 
A

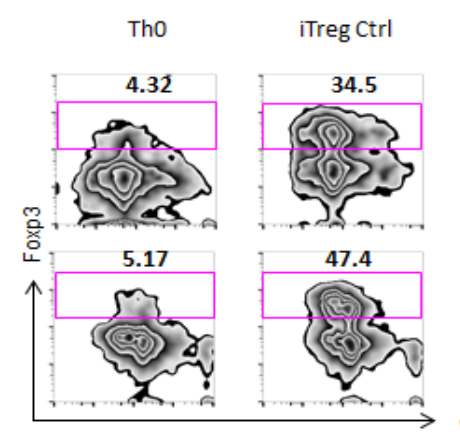

iTreg $1 \mu \mathrm{M}$

iTreg $5 \mu \mathrm{M}$

iTreg $10 \mu \mathrm{M}$
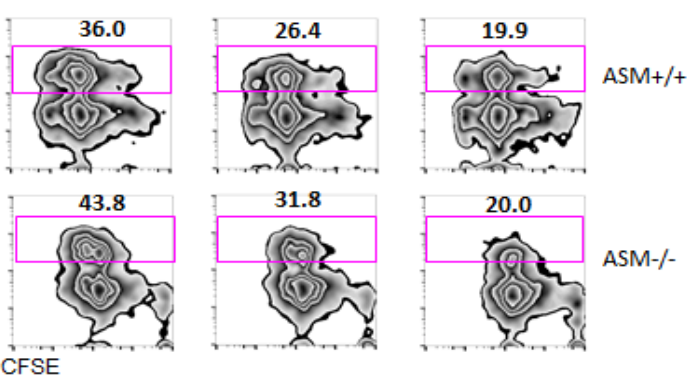

B

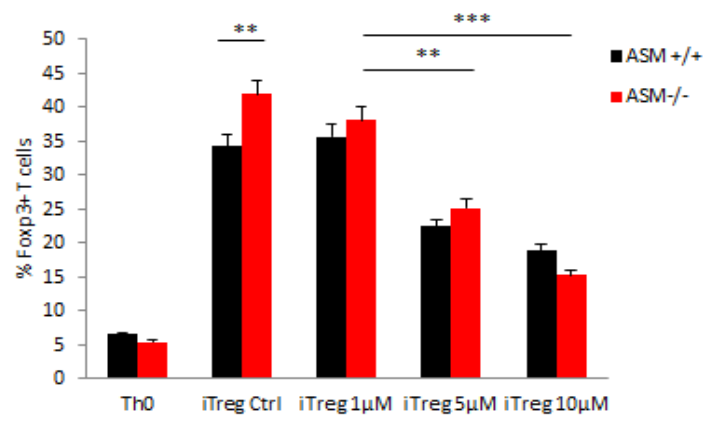

Fig. 4. Ceramide blunted iTreg induction and proliferation in both $\mathrm{ASM}^{+/+}$and $\mathrm{ASM}^{-/ \cdot}$ Purified CD4+ $\mathrm{T}^{+}$cells were stained with the cell proliferation dye CFSE $(2 \mu \mathrm{M})$ and cultured for 3 days with TGF- $\beta(5.0 \mathrm{ng} / \mathrm{ml})$ and IL-2 (10.0 ng/ml) (iTreg). After 3 days of culture, cells were stained with a Foxp3 antibody and acquired by flow cytometry. Flow data suggested iTreg in both $\mathrm{ASM}^{+/+}$and $\mathrm{ASM}^{-/}$mice have been blunted after ceramide treatment compared with untreated groups follow the dose dependent manners $(1 \mu \mathrm{M}-10 \mu \mathrm{M})$. (A) shows the representative FACS plots for Foxp3 and CFSE staining. (B) shows mean \pm SEM ( $\mathrm{n}=3-5$ independent experiments) for Th0 cells, iTregs and ceramide treated groups respectively. ${ }^{* *}$ and ${ }^{* * *}$ indicate statistical significance difference $(p<0.01)$ or $(p<0.001)$ respectively.

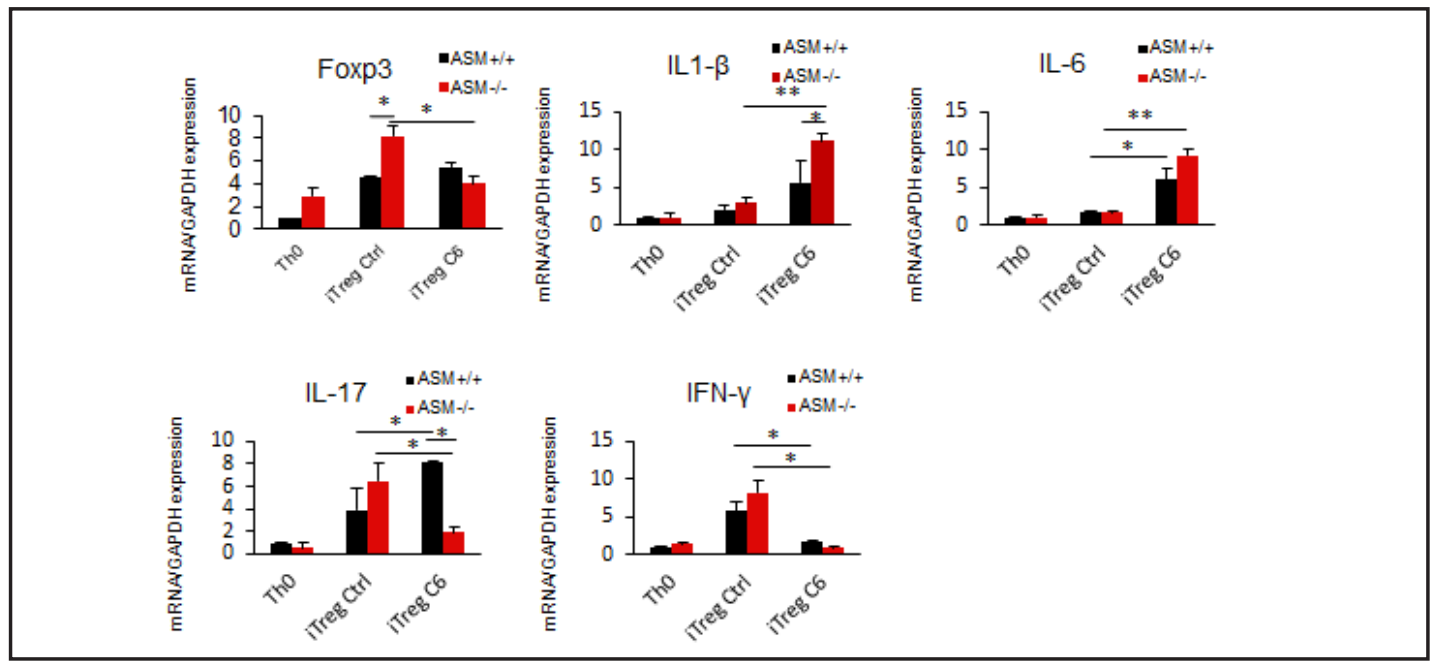

Fig. 5. Ceramide induces IL-1 $\beta$, IL-6 and IL-17 mRNA transcripts alongside the reduction of iTreg. RNA was isolated from Th0 and iTreg from $\mathrm{ASM}^{-/-}$as well $\mathrm{ASM}^{+/+}$iTreg and treated with $10 \mu \mathrm{M}$ Ceramide C6. RNA was subjected to cDNA preparation and qRT-PCR was performed for inflammatory cytokines genes $(I L-1 \beta, I L-6$, $I L-17$ and $I F N-\gamma$ ) as well as Foxp3 transcription factor. Data are derived from $\mathrm{n}=4$ independent experiments. $*$ and $* *$ indicate statistical significance difference $(p<0.05)$ or $(p<0.01)$ respectively. 


\section{Cellular Physiology Cell Physiol Biochem 2016;39:985-995 \\ \begin{tabular}{l|l|l} 
and BOI: 10.1159/000447806 & $\begin{array}{l}\text { (c) 2016 The Author(s). Published by S. Karger AG, Basel } \\
\text { www.karger.com/cpb }\end{array}$
\end{tabular} \\ Zhou et al.: ASM Plays a Key Role in Treg Development}

Ceramide C6 treatment decreases the iTreg development

The ASM enzyme is involved in the hydrolysis of sphingolipids into ceramide [22]. One of the most studied roles of ceramide pertains to its function as a proapoptotic molecule. We speculated that ceramide could impair the development of iTreg. To test this hypothesis, naïve T cells were differentiated in the presence of Ceramide C6 $(1 \mu \mathrm{M}-10 \mu \mathrm{M})$. As a result, Ceramide C6 $(10 \mu \mathrm{M})$ significantly reduced the development and proliferation of iTreg from both $\mathrm{ASM}^{-/-}$and $\mathrm{ASM}^{+/+}$mice strains (Fig. $4 \mathrm{~A}$ and B).

\section{Ceramide C6 treatment increased the IL-17 from iTreg}

We further explored whether a decrease in iTreg production, lead to an increase in inflammation after treatment with Ceramide C6. In keeping with previous results above, iTreg has significantly more Foxp $3^{+}$mRNA levels in ASM ${ }^{--}$mice (Fig. 5). mRNA levels of $I L-1 \beta$ and $I L-6$ were significantly higher in iTreg treated with Ceramide C6 $(10 \mu \mathrm{M})$ compared with control iTreg in both mice strains (Fig. 5). In contrast, $I L-17$ mRNA levels were significantly augmented in $\mathrm{ASM}^{+/+}$iTreg treated with Ceramide C6. Surprisingly, only $I L-17$ mRNA levels were decreased after ceramide treatment in iTreg from ASM ${ }^{-/}$mice (Fig. 5). However, mRNA levels of $I F N-\gamma$ were reduced in both strains of mice Treg (Fig. 5) after Ceramide C6 treatment. Thus, our data suggested that decrease in iTreg development treatment with Ceramide C6 increases the mRNA levels of various inflammatory cytokines.

\section{Discussion}

Sphingolipids participate in the pathophysiology of cancer, neurodegeneration, neuroinflammation as well as autoimmune disorders [21, 24, 27, 28]. However, how ASM is involved in the development of Treg had not been defined. In this manuscript, we describe a novel role of ASM in iTreg development. ASM derived ceramide negatively regulates the development of iTreg. Accordingly, ASM deficient mice have increased formation of Treg in vitro and in vivo. Further, we uncover that ceramide is a key regulator of IL-1 $\beta$, IL- 6 and IL-17 mRNA levels in developing iTreg.

A previous study suggested that intravenous injection of anti-CD4 antibody or phytohemagglutinin (PHA) results in apoptosis of peripheral blood lymphocytes through the endogenous CD95/CD95 ligand in control mice but not in ASM deficient mice [28]. Furthermore, control mice but not ASM deficient mice develop autoimmune like hepatitis after treatment with PHA or anti-CD4 [28]. According to our observations, higher numbers of Tregs in ASM deficient mice could explain the blunted development of autoimmune like hepatitis in ASM deficient mice.

Sphingolipids are lipid molecules governing diverse processes such as inflammatory signalling, cell death, and cell proliferation [18]. Our data suggests that iTreg proliferation was lower in ASM deficient mice compared with control mice. However, no difference was observed in iTreg cell death between both mice strains. Our cell cycle analysis shows that ASM deficient mice have lower G0/G1 phase compared with control littermate mice, suggesting that T cells are more proliferative in ASM deficient mice. Furthermore, mTOR, Rictor, pS6 kinase and AKT signalling molecules are less in iTreg from ASM deficient mice, on observation providing an explanation for increased induction of iTreg $[35,36]$. A previous study suggested that ceramide regulates lipopolysaccharide (LPS)-induced phosphatidylinositol 3-kinase and AKT activity in human alveolar macrophages immune cells [37]. AKT is critical in governing the development of Treg and TCR induced ceramide production leads to reduced Treg development. In keeping this view, our results suggested that ASM deficient iTreg have reduced AKT and mTOR activities compared with control Treg due to lack of ceramide production. Thus, our data are pointing out a potential link between ASM/ceramide and Treg development via AKT.

Sphingolipids are one of the main components of the plasma membrane and their level of expression is decisive for the regulation of a variety of cell functions [19]. Sphingomyelinases 


\section{Cellular Physiology Cell Physiol Biochem 2016;39:985-995

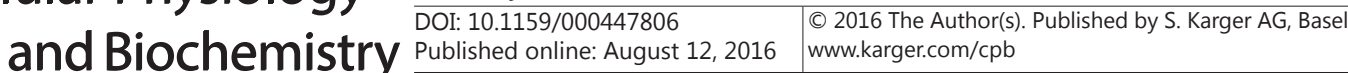 \\ Zhou et al.: ASM Plays a Key Role in Treg Development}

are rate limiting enzymes implicated in synthesis of ceramide [19]. ASM deficiency leads to less production of inflammatory products such as ceramide $[19,20]$. Our experiments suggest that ceramide leads to less induction of iTreg in control mice. In addition to this, ASM deficient mice which have enhanced iTreg are also able to lose the Foxp3 induction when treated with ceramide. These results confirm that the ASM product ceramide could lead to decreased iTreg development. However, our results are in sharp contrast to previously findings [38]. Discrepancies in the results could be due different methods of iTreg induction. In our experiments, we have used IL-2 in addition to TGF- $\beta$ for iTreg whereas the previously published study used only TGF- $\beta$. Indeed, at lower concentration $(1 \mu \mathrm{M})$ in our hands, we found slight increase in iTreg induction, however at higher concentrations ( $5 \mu \mathrm{M}$ or $10 \mu \mathrm{M}) \mathrm{a}$ sharp decline in iTreg induction not only in control but also in ASM deficient mice.

Ceramide is an inflammatory mediator generated after ASM activity. Our data suggest that ceramide treatment leads to enhanced production of IL-1 $\beta$ and IL- 6 mRNAs. IL-17 mRNA was also enhanced in WT mice, although, IL-17 levels were reduced even after treatment with ceramide. Nonetheless, our data suggest a key function of ceramide and ASM in suppression of iTreg induction during inflammation.

\section{Conclusion}

In summary, we have shown that ASM is crucial in maintaining the balance between inflammatory and suppressive functions of Tregs. Ceramide generated by ASM could enhance the inflammatory environment during iTreg generation and leads to lower production of iTreg.

\section{Acknowledgements}

The study was supported by the Deutsche Forschungsgemeinschaft and Open Access Publishing Fund of Tuebingen University.

\section{Disclosure Statement}

The authors have nothing to disclose.

\section{References}

1 Agarwal A, Fanelli G, Letizia M, Tung SL, Boardman D, Lechler R, Lombardi G, Smyth LA: Regulatory T cell-derived exosomes: possible therapeutic and diagnostic tools in transplantation. Front Immunol 2014;5:555.

2 Singer BD, King LS, D'Alessio FR: Regulatory T cells as immunotherapy. Front Immunol 2014;5:46.

3 Zhou X, Bailey-Bucktrout S, Jeker LT, Bluestone JA: Plasticity of CD4(+) FoxP3(+) T cells. Curr Opin Immunol 2009;21:281-285.

4 Cording S, Fleissner D, Heimesaat MM, Bereswill S, Loddenkemper C, Uematsu S, Akira S, Hamann A, Huehn J: Commensal microbiota drive proliferation of conventional and Foxp3(+) regulatory CD4(+) T cells in mesenteric lymph nodes and Peyer's patches. Eur J Microbiol Immunol (Bp) 2013;3:1-10.

5 Himmel ME, Yao Y, Orban PC, Steiner TS, Levings MK: Regulatory T-cell therapy for inflammatory bowel disease: more questions than answers. Immunology 2012;136:115-122.

6 Ottenhoff TH: New pathways of protective and pathological host defense to mycobacteria. Trends Microbiol 2012;20:419-428. 


\section{Cellular Physiology Cell Physiol Biochem 2016;39:985-995 \begin{tabular}{l|l|l|}
\hline DOI: 10.1159/000447806 & $\begin{array}{l}\text { C) 2016 The Author(s). Published by S. Karger AG, Basel } \\
\text { www.karger.com/cpb }\end{array}$ \\
\hline
\end{tabular} \\ Zhou et al.: ASM Plays a Key Role in Treg Development}

7 Smith PM, Howitt MR, Panikov N, Michaud M, Gallini CA, Bohlooly YM, Glickman JN, Garrett WS: The microbial metabolites, short-chain fatty acids, regulate colonic Treg cell homeostasis. Science 2013;341:569-573.

8 Tousif S, Singh Y, Prasad DV, Sharma P, Van Kaer L, Das G: T cells from Programmed Death-1 deficient mice respond poorly to Mycobacterium tuberculosis infection. PLoS One 2011;6:e19864.

9 Scott-Browne JP, Shafiani S, Tucker-Heard G, Ishida-Tsubota K, Fontenot JD, Rudensky AY, Bevan MJ, Urdahl KB: Expansion and function of Foxp3-expressing T regulatory cells during tuberculosis. J Exp Med 2007;204:2159-2169.

10 Reynolds AD, Banerjee R, Liu J, Gendelman HE, Mosley RL: Neuroprotective activities of CD4+CD25+ regulatory T cells in an animal model of Parkinson's disease. J Leukoc Biol 2007;82:1083-1094.

11 Singh Y, Chen H, Zhou Y, Föller M, Mak TW, Salker MS, Lang F: Differential effect of DJ-1/PARK7 on development of natural and induced regulatory T cells. Sci Rep 2015;5:17723.

12 Chen W, Konkel JE: TGF-beta and 'adaptive' Foxp3(+) regulatory T cells. J Mol Cell Biol 2010;2:30-36.

13 Fantini MC, Dominitzki S, Rizzo A, Neurath MF, Becker C: In vitro generation of CD4+ CD25+ regulatory cells from murine naive T cells. Nat Protoc 2007;2:1789-1794.

14 Wu Y, Borde M, Heissmeyer V, Feuerer M, Lapan AD, Stroud JC, Bates DL, Guo L, Han A, Ziegler SF, Mathis D, Benoist C, Chen L, Rao A: FOXP3 controls regulatory T cell function through cooperation with NFAT. Cell 2006;126:375-387.

15 Fontenot JD, Gavin MA, Rudensky AY: Foxp3 programs the development and function of CD4+CD25+ regulatory T cells. Nat Immunol 2003;4:330-336.

16 Fontenot JD, Rasmussen JP, Williams LM, Dooley JL, Farr AG, Rudensky AY: Regulatory T cell lineage specification by the forkhead transcription factor foxp3. Immunity 2005;22:329-341.

17 Gavin MA, Rasmussen JP, Fontenot JD, Vasta V, Manganiello VC, Beavo JA, Rudensky AY: Foxp3-dependent programme of regulatory T-cell differentiation. Nature 2007;445:771-775.

18 Airola MV, Hannun YA: Sphingolipid metabolism and neutral sphingomyelinases. Handb Exp Pharmacol 2013;10.1007/978-3-7091-1368-4_357-76.

19 Kamil B, Anna F, Anna S, Slawomir P, Halina C: Regulation of sphingomyelin metabolism. Pharmacol Rep 2016;68:570-581.

20 Jenkins RW, Canals D, Hannun YA: Roles and Regulation of Secretory and Lysosomal Acid Sphingomyelinase. Cell Signal 2009;21:836-846.

21 Lopes Pinheiro MA, Kroon J, Hoogenboezem M, Geerts D, van Het Hof B, van der Pol SM, van Buul JD, de Vries HE: Acid Sphingomyelinase-Derived Ceramide Regulates ICAM-1 Function during T Cell Transmigration across Brain Endothelial Cells. J Immunol 2016;196:72-79.

22 Horinouchi K, Erlich S, Perl DP, Ferlinz K, Bisgaier CL, Sandhoff K, Desnick RJ, Stewart CL, Schuchman EH: Acid sphingomyelinase deficient mice: a model of types A and B Niemann-Pick disease. Nat Genet 1995;10:288-293.

23 Lee JK, Jin HK, Park MH, Kim BR, Lee PH, Nakauchi H, Carter JE, He X, Schuchman EH, Bae JS: Acid sphingomyelinase modulates the autophagic process by controlling lysosomal biogenesis in Alzheimer's disease. J Exp Med 2014;211:1551-1570.

24 Assi E, Cervia D, Bizzozero L, Capobianco A, Pambianco S, Morisi F, De Palma C, Moscheni C, Pellegrino P, Clementi E, Perrotta C: Modulation of Acid Sphingomyelinase in Melanoma Reprogrammes the Tumour Immune Microenvironment. Mediators Inflamm 2015;2015:370482.

25 Carpinteiro A, Becker KA, Japtok L, Hessler G, Keitsch S, Pozgajova M, Schmid KW, Adams C, Muller S, Kleuser B, Edwards MJ, Grassme H, Helfrich I, Gulbins E: Regulation of hematogenous tumor metastasis by acid sphingomyelinase. EMBO Mol Med 2015;7:714-734.

26 Peng H, Li C, Kadow S, Henry BD, Steinmann J, Becker KA, Riehle A, Beckmann N, Wilker B, Li PL, Pritts T, Edwards MJ, Zhang Y, Gulbins E, Grassme H: Acid sphingomyelinase inhibition protects mice from lung edema and lethal Staphylococcus aureus sepsis. J Mol Med (Berl) 2015;93:675-689.

27 Perrotta C, Cervia D, De Palma C, Assi E, Pellegrino P, Bassi MT, Clementi E: The emerging role of acid sphingomyelinase in autophagy. Apoptosis 2015;20:635-644.

28 Kirschnek S, Paris F, Weller M, Grassme H, Ferlinz K, Riehle A, Fuks Z, Kolesnick R, Gulbins E: CD95mediated apoptosis in vivo involves acid sphingomyelinase. J Biol Chem 2000;275:27316-27323. 


\section{Cellular Physiology Cell Physiol Biochem 2016;39:985-995

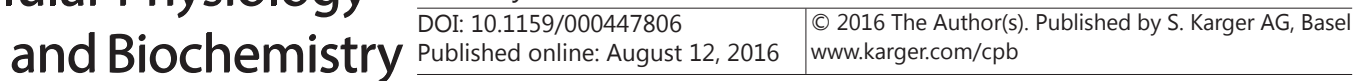 \\ Zhou et al.: ASM Plays a Key Role in Treg Development}

29 Munzer P, Borst O, Walker B, Schmid E, Feijge MA, Cosemans JM, Chatterjee M, Schmidt EM, Schmidt S, Towhid ST, Leibrock C, Elvers M, Schaller M, Seizer P, Ferlinz K, May AE, Gulbins E, Heemskerk JW, Gawaz M, Lang F: Acid sphingomyelinase regulates platelet cell membrane scrambling, secretion, and thrombus formation. Arterioscler Thromb Vasc Biol 2014;34:61-71.

30 Herz J, Pardo J, Kashkar H, Schramm M, Kuzmenkina E, Bos E, Wiegmann K, Wallich R, Peters PJ, Herzig S, Schmelzer E, Kronke M, Simon MM, Utermohlen O: Acid sphingomyelinase is a key regulator of cytotoxic granule secretion by primary T lymphocytes. Nat Immunol 2009;10:761-768.

31 Lepple-Wienhues A1, Belka C, Laun T, Jekle A, Walter B, Wieland U, Welz M, Heil L, Kun J, Busch G, Weller M, Bamberg M, Gulbins E, Lang F: Stimulation of CD95 (Fas) blocks T lymphocyte calcium channels through sphingomyelinase and sphingolipids. Proc Natl Acad Sci USA 1999;96:13795-13800.

32 Singh Y, Dyson J, Garden OA: Use of SNARF-1 to measure murine T cell proliferation in vitro and its application in a novel regulatory T cell suppression assay. Immunol Lett 2011;140:21-29.

33 Singh Y, Garden OA, Lang F, Cobb BS: MicroRNA-15b/16 Enhances the Induction of Regulatory T Cells by Regulating the Expression of Rictor and mTOR. J Immunol2015;10.4049/jimmunol.1401875

34 Merkenschlager M, von Boehmer H: PI3 kinase signalling blocks Foxp3 expression by sequestering Foxo factors. J Exp Med 2010;207:1347-1350.

35 Sauer S, Bruno L, Hertweck A, Finlay D, Leleu M, Spivakov M, Knight ZA, Cobb BS, Cantrell D, O'Connor E, Shokat KM, Fisher AG, Merkenschlager M: T cell receptor signaling controls Foxp3 expression via PI3K, Akt, and mTOR. Proc Natl Acad Sci U S A 2008;105:7797-7802.

36 Haxhinasto S, Mathis D, Benoist C: The AKT-mTOR axis regulates de novo differentiation of CD4+Foxp3+ cells. J Exp Med 2008;205:565-574.

37 Monick MM, Mallampalli RK, Carter AB, Flaherty DM, McCoy D, Robeff PK, Peterson MW, Hunninghake GW: Ceramide regulates lipopolysaccharide-induced phosphatidylinositol 3-kinase and Akt activity in human alveolar macrophages. J Immunol 2001;167:5977-5985.

38 Kue CS, Lim HX, Jung MY, Hong HJ, Cho D, Kim TS: C6-ceramide in combination with transforming growth factor-beta enhances Treg cell differentiation and stable FoxP3 expression in vitro and in vivo. Immunobiology 2013;218:952-959. 